\title{
Clinical correlates of postmortem brain changes in schizophrenia: decreased brain weight and length correlate with indices of early impairment
}

\author{
E C Johnstone, C J Bruton, T J Crow, C D Frith, D G C Owens
}

University

Department of

Psychiatry, The

Kennedy Tower, Royal

Edinburgh Hospital,

Morningside Park,

Edinburgh EH10 5HF,

UK

E C Johnstone

D G C Owens

Department of

Neuropathology,

Runwell Hospital,

Wickford, Essex SS11

7QE, UK

C J Bruton

Division of

Psychiatry, Clinical

Research Centre,

Watford Road,

Harrow, Middlesex,

HA1 3UJ, UK

T J Crow

MRC Cyclotron

Department,

Postgraduate Medical

School,

Hammersmith

Hospital, Du Cane

Road, London W12

OHS, UK

C D Frith

Correspondence to:

Professor E C Johnstone.

Received 5 January 1993

and in revised form

6 April 1993.

Accepted 14 July 1993

\begin{abstract}
From a postmortem study of the brains of 56 patients with schizophrenia and 56 controls, 38 cases whose clinical state had been objectively documented in life were examined to determine whether relations existed between features of the illness and postmortem findings. Decreased brain weight was significantly related $(p<0.05)$ to poor premorbid global function and to poor academic record, and decreased brain length was related to poorer premorbid global function $(p<0.05)$ and more severe negative symptoms. These relations are consistent with the view that morphological changes in the brain occur early in the course of the disease-that is, they are in some sense "developmental." An excess of "focal damage" in the patient group relative to controls was unrelated to the presence of morphological change or to features of illness, but was more common in female schizophrenic patients and was also correlated with evidence of cerebrovascular disease. This may possibly be due to a discrepancy between the groups in mode and cause of death.
\end{abstract}

\section{(F Neurol Neurosurg Psychiatry 1994;57:474-479)}

The idea that schizophrenia may be associated with structural brain changes is as old as the concept of the disease and may indeed precede its clear definition. In 1857 Griesinger ${ }^{1}$ defined the brain as the site of mental disease. In 1891 Clouston $^{2}$ wrote of abnormalities of the CNS as a feature of the disorder that he called adolescent insanity and later considered this as part of Kraepelin's concept of dementia praecox, ${ }^{3}$ which came to be known as schizophrenia. In 1907 Kraepelin $^{4}$ stated that "the morbid anatomy has disclosed not simple inadequacy of the nervous system but destructive morbid processes as the background of the clinical picture".

Despite the confident assertions of these early workers, nine decades of endeavour have not provided unequivocal evidence of these destructive morbid processes. Kraepelin's work was shortly followed by a histological investigation by Alzheimer ${ }^{5}$ in which he described cell loss and gliosis in schizophrenia. In 1924 Dunlap $^{6}$ described a study in which three independent observers made cell counts of the cortical layers in which changes in schizophrenia had been observed by Alzheimer and found no difference between schizophrenic patients and controls. Cellular changes similar to those that had been described in schizophrenia were found in both groups. This study cast doubt over the histopathological study of schizophrenia, which persisted for many years and is evident in later reviews. $^{7}$

Since the 1920s the issue of structural change in the brain in schizophrenia has been investigated by imaging as well as by pathological studies. ${ }^{8}$ In 1929 the American Roentgen Ray Society declared that it was unethical to use pneumoencephalography in normal controls, thus limiting the methodology of many consequent studies. The introduction of the non-invasive technique of CT by Hounsfield ${ }^{9}$ in 1973 overcame this difficulty and a series of comparisons of the structure of the brain in schizophrenia with that in control subjects began in $1976 .{ }^{10}$ Most, but not all, comparisons showed significant differences between those with schizophrenia and controls, and it is concluded from an assessment of published work that an appreciable percentage of schizophrenic patients have subtle CT abnormalities including ventricular and possibly sulcal enlargement. ${ }^{11}$ These findings have stimulated a renewal of interest in histopathology of the brain in schizophrenia. ${ }^{12-14}$ These investigations, similar to those of brain weights and volumes conducted by Brown et al ${ }^{15}$ and Pakkenberg, ${ }^{16}$ were retrospective and depended on diagnosis from case notes. Clearly a prospective cliniconeuropathological investigation of the brains of patients with schizophrenia who had been diagnosed in life compared with those who were known not to have had psychiatric or neurological disorders during their lifetime would be helpful in this situation, and one has been conducted. ${ }^{17}$ Significant differences between patients with schizophrenia and controls in terms of brain weight, brain length (schizophrenic patients had lighter and shorter brains) and the presence of non-specific focal pathology and fibrillary gliosis (both more frequent in schizophrenic patients) were found. ${ }^{17}$

Many of the schizophrenic patients in that study had been examined during their lifetime in connection with various investigations. ${ }^{18-22}$ Historical information had been recorded in detail and clinical, neurological, and psychological state had been assessed in a standardised manner. This report is concerned with 
the relation between these clinical assessments in schizophrenic patients and the pathological findings.

\begin{abstract}
Method
Brains from the 56 schizophrenic patients and 56 normal controls were weighed fresh, then bisected by a midline sagittal section; one half was frozen at $-70^{\circ} \mathrm{C}$ for subsequent neurochemical study. The remaining half was placed medial surface downwards in a plastic container to avoid distortion artefacts and fixed in $10 \%$ formalin for four weeks. Full details of the postmortem procedure, measurements, and histological assessments have already been described. ${ }^{17}$ Each brain was coded and later examined without knowledge of the clinical history. Thirty eight of the schizophrenic patients had been included in the original large study of inpatients at Shenley Hospital ${ }^{18}$ and some of them survived to be included in later studies. ${ }^{19-22}$ Historical information was recorded for the initial study, but the methods used for the assessments of mental state were the same for all of the investigations and the ratings used for this study were those conducted closest to the patient's death. This interval was never more than three years and in one case was five days. All 38 patients fulfilled the St Louis criteria for schizophrenia. ${ }^{23}$ At the end of the study, when the neuropathological code numbers were compared with the relevant case histories, it was found that five of the Shenley schizophrenic patients had added neurological complications. Three of these related to previous
\end{abstract}

Table 1 Historical information related to postmortem findings

\begin{tabular}{|c|c|c|}
\hline $\begin{array}{l}\text { Specification of } \\
\text { variable }\end{array}$ & $\begin{array}{l}\text { No of cases in } \\
\text { whom variable } \\
\text { was available }\end{array}$ & Source of information \\
\hline $\begin{array}{l}\text { Sex, age, age at first admission, } \\
\text { duration of illness }\end{array}$ & 33 & Original Shenley survey ${ }^{18}$ \\
\hline $\begin{array}{l}\text { Premorbid academic functioning } \\
\text { (university or equivalent, average } \\
\text { attainment, remedial teaching or } \\
\text { equivalent) }\end{array}$ & 32 & Original Shenley survey ${ }^{18}$ \\
\hline $\begin{array}{l}\text { Premorbid global functioning } \\
\text { (occupational and social attainments } \\
\text { as recorded for survey) best } \\
\text { sustained occupational and social } \\
\text { attainments as recorded for survey }\end{array}$ & 32 & $\begin{array}{l}\text { Re-examination of } \\
\text { survey }^{18} \text { to derive composite } \\
\text { score, done blindly before } \\
\text { postmortems }\end{array}$ \\
\hline Family history of mental disorder & 33 & Original Shenley survey ${ }^{18}$ \\
\hline $\begin{array}{l}\text { Physical treatment (ECT, insulin coma, } \\
\text { neuroleptics cardiazol, TAB vaccine, } \\
\text { dexedrine) }\end{array}$ & 33 & $\begin{array}{l}\text { Original Shenley survey }{ }^{18} \\
\text { and updating }\end{array}$ \\
\hline $\begin{array}{l}\text { Other generalised illness (for example, } \\
\text { diabetes, DU surgery for hypernephroma) }\end{array}$ & 33 & $\begin{array}{l}\text { Original Shenley survey }{ }^{18} \\
\text { and review of notes at death } \\
\text { done blindly before } \\
\text { postmortems }\end{array}$ \\
\hline $\begin{array}{l}\text { Peculiar circumstances (any unusual } \\
\text { circumstances that could be of } \\
\text { relevance- for instance, inmate of DP } \\
\text { camp. FH of major neurological anomaly) }\end{array}$ & 33 & $\begin{array}{l}\text { Original Shenley survey }{ }^{18} \\
\text { and review of information } \\
\text { obtained for same }\end{array}$ \\
\hline Birth trauma/head injury & 19 & $\begin{array}{l}\text { Information recorded from } \\
\text { patients' mothers at time of } \\
\text { first admission. Not } \\
\text { recorded in remaining } 14 \\
\text { cases }\end{array}$ \\
\hline
\end{tabular}

DU, duodenal ulcer; DP, displaced persons; FH, family history. treatment (leucotomy) and one patient had had a terminal cerebrovascular accident. The remaining case had developed a psychotic illness in the absence of detectable neurological abnormality, while working as a ballerina, and this illness fulfilled the St Louis criteria for schizophrenia. ${ }^{23}$ She later developed motor and cerebellar signs and postmortem examination confirmed the diagnosis of multiple sclerosis. Thirty three brains therefore remained from patients who fulfilled the $S t$ Louis criteria for schizophrenia, had been documented and systematically examined in life, and who did not have added neurological complications. A large amount of data had been collected for the patients in Shenley at the time of the original survey and it would have been inappropriate to examine the large number of variables in relation to the small number of brains available for postmortem examination. Full data were not available in every case because of some incomplete early histories, and table 1 details the historical information used. Family histories were obtained at admission and were generally not updated thereafter. The frequency of a definite or possible family history of schizophrenia is therefore likely to be underestimated.

These patients had also been examined in life, although one was too unwell (near death) when she was first seen to cooperate with mental state examination or cognitive testing, and thus was only assessed for movement (hyperkinetic) disorder.

The assessments were positive features ${ }^{24}$ available in 32 cases; negative features ${ }^{24}$ available in 32 cases; cognitive functioning $^{25}$-available in 26 cases; and hyperkinetic disorder assessed as present or absent-available in 33 cases. The scale of Krawiecka ${ }^{24}$ and the test battery of Withers and Hinton ${ }^{25}$ had been used in the repeated assessments of these patients and could therefore be used for this study, but the assessments of movement disorder were changed ${ }^{1819}$ and the simple assessment of present or absent is the most accurate available to us.

\section{STATISTICAL ANALYSIS}

As previously reported, ${ }^{17}$ in the prospective cliniconeuropathological comparisons there were five variables that distinguished schizophrenic patients from controls - namely, brain weight, brain length, ventricle size, focal damage, and gliosis. Gliosis and focal damage were related and independent of the other more general brain changes. The intention of this study was to see whether any of these neuropathological changes relate to clinical features (either historical or examination variables). This was done by stepwise regression. For example, the schizophrenic patients were divided into two groups on the basis of whether or not they had focal damage or gliosis, (see Bruton et $a^{17}$ ). Logistic stepwise regression was then used to see whether the membership of these two groups could be predicted from clinical variables (using the statistical package BMDP LR). The clinical variables used were subclassified as: $(a)$ sex, 
age, age at first admission, duration of illness; (b) positive features, negative features, premorbid functioning (academic and global); (c) results on Withers and Hinton test (cognitive functioning); (d) birth trauma, head injury; (e) movement disorder (noted as hyperkinetic disorder present or absent); $(f)$ additional variables where information applied to few patients or was otherwise imperfect (the use or not of "other treatments"; a history or not of "peculiar circumstances"; a history or not of generalised illness; a family history of definite or possible schizophrenia).

Because of incomplete data (table 1) these variables were examined in various subsetsnamely, set $(a)$, set $(a+b)$, set $(a)+(b)+$ (c), set (a) + (d), set (a) + (e), set (a) + (f). In the linear regression the model was forced to apply age and sex before any of the other variables, as they are known to be strong determinants of measures such as brain weight and brain length. All results reported are derived from this analysis.

\section{Results}

RELATIONS BETWEEN BRAIN WEIGHT AND CLINICAL VARIABLES

There were significant relations between brain weight and age and sex, such that females had lower brain weights than males $(p<0.01)$ and greater age was associated with lower brain weight $(p<0.01)$. Also, lower brain weight was significantly associated with poorer premorbid global function $(p<0.05)$ and with poorer cognitive function. Lower brain weight was significantly related to both poorer premorbid academic record $(p<0.01)$ and to poorer performance on the test battery of Withers and Hinton ${ }^{25}(p<0.01)$ when exam-
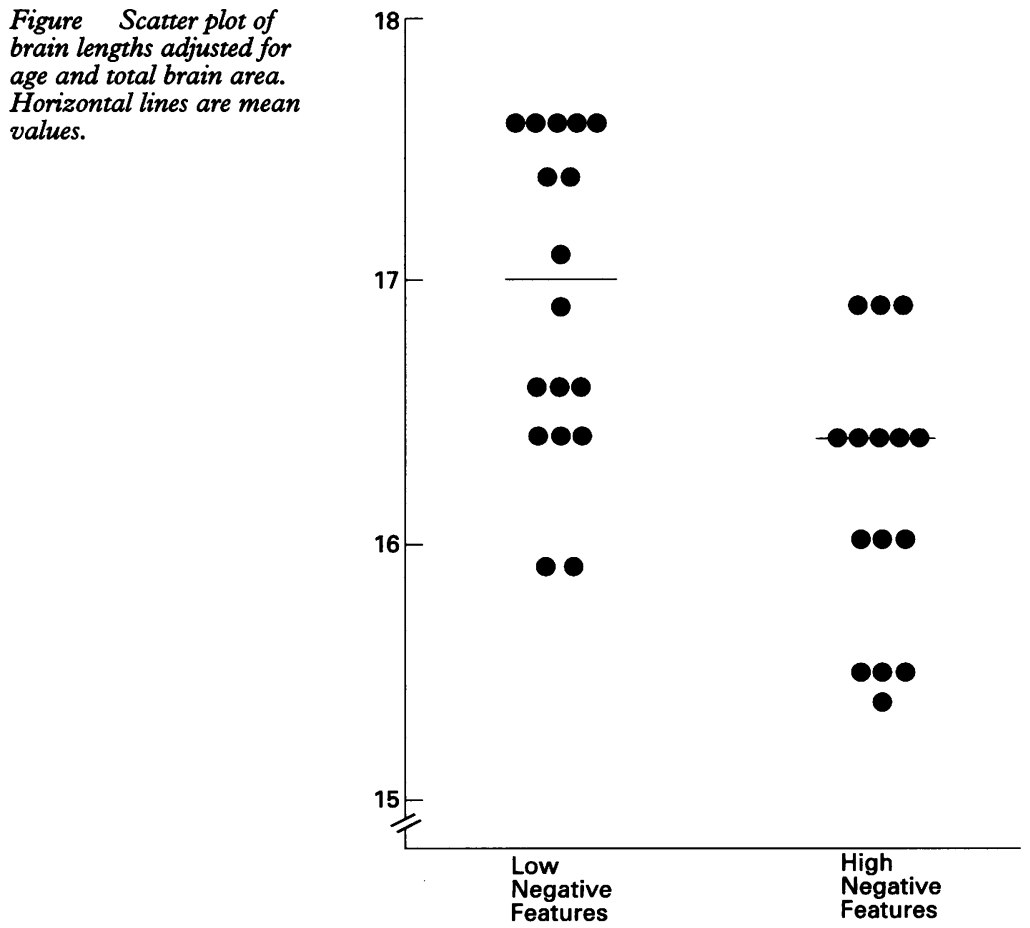

ined for the survey ${ }^{18}$ or later. The effects of these two variables were independent. Thus, the Withers and Hinton scores predicted brain weight even when premorbid academic level was taken into account. This does not necessarily indicate a role for cognitive decline. Premorbid academic level was defined by only three categories: university or equivalent; average; poor.

\section{RELATIONS BETWEEN BRAIN LENGTH AND}

CLINICAL VARIABLES

Women's brains were significantly shorter than those of men $(p<0.01)$. Also, there were significant associations $(p<0.05)$ between shorter brains and poorer premorbid global function and between shorter brains and more severe negative symptoms $(p<$ 0.02; Figure).

\section{RELATIONS BETWEEN VENTRICLE SIZE AND}

CLINICAL VARIABLES

As expected, there was a significant relation ( $p$ $<0.01$ ) between increasing age and greater ventricle size. Otherwise there were no relations between clinical variables and ventricular size.

RELATIONS BETWEEN FOCAL DAMAGE AND CLINICAL VARIABLES AND BETWEEN GLIOSIS AND CLINICAL VARIABLES

When all the samples from schizophrenic patients and controls were examined some degree of localised cerebral pathology (focal damage) was found in $44 \%$ of the schizophrenic patients and $21 \%$ of controls $(p<$ $0.01) .{ }^{17}$ The nature and localisation of such pathology was diverse and included such apparently unrelated entities as degeneration of the substantia nigra, calcification of the hippocampus, a ganglioglioma of the pons, focal softening of the cerebellum, and infarction of the striatum. In the group of 33 schizophrenic patients in the present study, focal damage was significantly related only to sex, being less likely to be found in men $(p<$ $0.02)$. In the total sample, ${ }^{17}$ there was a strong positive relation $(p<0.01)$ between both cortical and white matter gliosis and the presence of focal damage. In the 33 cases considered here, there was no relation between periventricular gliosis and any clinical variables, and for cortical gliosis there was only a marginal relation with age $(p<0.09)$. The statistical analysis of the historical information involved grouping together variables that were not necessarily related and the individual details in patients with and without focal damage were therefore scrutinised (table 2); apart from some differences in exposure to unusual treatments, the two groups were similar.

OTHER RELATIONS

Movement disorder was not related to any pathological finding, nor were birth trauma, head injury, any form of physical treatment including insulin coma, the presence of generalised illness, "peculiar circumstances", family history of schizophrenia, or of mental disorder. 
Table 2 Comparison of items of historical information between those with and without focal damage

\begin{tabular}{|c|c|c|}
\hline & $\begin{array}{l}\text { Focal damage } \\
\text { ( } 4 \text { males; } 8 \text { females) }\end{array}$ & $\begin{array}{l}\text { No focal damage } \\
\text { (14 males; } 7 \text { females) }\end{array}$ \\
\hline Birth trauma & $\begin{array}{l}7 \text { no trauma } \\
5 \text { no information }\end{array}$ & $\begin{array}{l}1 \text { forceps } \\
1 \text { kept in hospital for } \\
\text { prematurity } \\
7 \text { no trauma } \\
12 \text { no information }\end{array}$ \\
\hline Head injury & $\begin{array}{l}3 \text { no information } \\
2 \text { injury in childhood } \\
1 \text { fractured skull } \\
\text { psychotic behaviour }\end{array}$ & $\begin{array}{l}12 \text { no information } \\
6 \text { no injury } \\
2 \text { injury in childhood } \\
1 \text { later injury }\end{array}$ \\
\hline $\begin{array}{l}\text { Other generalised } \\
\text { illness }\end{array}$ & $\begin{array}{l}7 \text { no illness } \\
1 \text { diabetes } \\
1 \text { duodenal ulcer } \\
1 \text { surgery to nose } \\
1 \text { nephrectomy and } \\
\text { splenectomy } \\
1 \text { unsustained positive test } \\
\text { for syphilis on admission }\end{array}$ & $\begin{array}{l}16 \text { no illness } \\
1 \text { diabetes } \\
1 \text { hysterectomy } \\
1 \text { pneumonia and } \\
\text { peritonitis } \\
1 \text { bilirubinaemia } \\
\text { ? cause } \\
1 \text { no information }\end{array}$ \\
\hline "Peculiar circumstances" & 12 no history & $\begin{array}{l}1 \text { inmate of camp } \\
\text { for displaced persons } \\
2 \text { children died } \\
\text { (1 spina bifida, } \\
1 \text { meningitis) } \\
19 \text { no history }\end{array}$ \\
\hline $\begin{array}{l}\text { History of treatment } \\
\text { with ECT at time } \\
\text { of last assessment } \\
\text { before death }\end{array}$ & $\begin{array}{l}4 \text { had ECT } \\
8 \text { no ECT }\end{array}$ & $\begin{array}{l}8 \mathrm{had} \text { ECT } \\
13 \text { no ECT }\end{array}$ \\
\hline $\begin{array}{l}\text { History of neuroleptic } \\
\text { ingestion at time of } \\
\text { last assessment } \\
\text { before death }\end{array}$ & $\begin{array}{l}5 \text { no neuroleptics } \\
7 \text { standard doses of } \\
\text { various neuroleptics }\end{array}$ & $\begin{array}{l}10 \text { no neuroleptics } \\
11 \text { standard doses } \\
\text { various neuroleptics }\end{array}$ \\
\hline $\begin{array}{l}\text { Unusual physical } \\
\text { treatment }\end{array}$ & $\begin{array}{l}6 \text { none } \\
4 \text { TAB vaccine } \\
2 \text { cardiazol }\end{array}$ & $\begin{array}{l}17 \text { none } \\
2 \text { dexedrine } \\
1 \text { ephedrine } \\
1 \text { modified narcosis }\end{array}$ \\
\hline $\begin{array}{l}\text { Insulin coma } \\
\text { treatment }\end{array}$ & $\begin{array}{l}10 \text { none } \\
2 \text { some }\end{array}$ & $\begin{array}{l}20 \text { none } \\
1 \text { some }\end{array}$ \\
\hline $\begin{array}{l}\text { Family history of } \\
\text { schizophrenia }\end{array}$ & $\begin{array}{l}2 \text { no information } \\
4 \text { no family history } \\
2 \text { family history of nervous } \\
\text { illness not schizophrenia } \\
1 \text { family history of } \\
\text { permanent stay in } \\
\text { hospital for } \\
\text { nervous illness } \\
3 \text { family history of schizophrenia }\end{array}$ & $\begin{array}{l}10 \text { no information } \\
3 \text { no family history } \\
\text { ( } 5 \text { family history of } \\
\text { nervous illness not } \\
\text { schizophrenia) } \\
3 \text { family history of } \\
\text { schizophrenia } \\
\text { (in all cases multiple } \\
\text { history) }\end{array}$ \\
\hline
\end{tabular}

\section{Discussion}

The clinicopathological comparison between the brains of schizophrenic patients and those of controls showed that schizophrenic brains are shorter, lighter, and more often show focal pathological change. The present study was to see if it is possible to relate the neuropathological findings in the brains of schizophrenic patients to clinical features of their condition. It is well known that the clinical picture, course, and outcome of schizophrenia, are by no means homogeneous. ${ }^{26}$

Although variations are restricted in this population, which consisted of patients with illnesses so severe that they had spent many years up until their deaths as long stay inpatients, there is a sufficient range of both historical and examination variables to allow us to examine relations with pathological features. This population was studied in unusual detail during life, and there is substantial information about their past treatment, their earlier functioning, their physical health, and unusual circumstances that they may have experienced. The opportunity of relating such information to pathological changes has rarely been available, but in this investigation there was no evidence that birth trauma, head injury, physical illness, unusual circumstances, exposure to ECT, insulin coma treatment or neuroleptics, related either to reduction in brain size or to focal damage. The exposure of the patients who had focal damage to unusual treatments was not the same as those who showed no such pathological change but it seems implausible that TAB vaccine and cardiazol could be of serious relevance to this issue.

Lower brain weight and shorter brain length were associated with impairments of global function, cognitive function, and negative symptoms. The relation between low brain weight and poor educational attainment need not necessarily reflect some process specific to schizophrenia. Such a relation might be found in the general population, although systematically collected information is not generally available. The additional and independent relation between low brain weight and poor recent cognitive levels (the Withers and Hinton test that was given in the last few years before death) is more difficult to interpret. Although it might reflect a neurodegenerative process in some patients, this seems unlikely because studies, including that of the postmortem material described here, ${ }^{17}$ have found little evidence for such degeneration. It is undoubtedly the case that many schizophrenic patients show a dramatic intellectual decline during their illness. Frith et $a l^{27}$ showed this to occur particularly in those whose intellectual level was low to begin with. In that study, however, cognitive decline was associated with negative features. In the present study it was brain length rather than brain weight that was associated with negative features. It is possible that the Withers and Hinton test is simply a more sensitive measure of a long standing intellectual deficit than educational attainment. These questions will not be resolved until larger samples of patients who have been assessed in life can be studied at postmortem examination. There was no relation between focal damage and most historical or examination variables, the only significant association being with sex (females had more focal damage than males, $\mathrm{p}<0.02$ ). In considering these results the two main pathological findings: (a) reduction in brain weight and length and $(b)$ the presence of focal damage, require separate discussion. A reduction in brain weight has been previously reported at postmortem examination ${ }^{15} 16$ consistent with some radiological studies ${ }^{28-30} \mathrm{sug}$ gesting a decrease in brain size.

The small but widely replicated increase in ventricular size that is characteristic of the schizophrenic population in general ${ }^{21} 3132$ may also be explicable as a reduction in cerebral mass. One interpretation of these findings is that they represent a failure of development rather than a degenerative process. Consistent with this view is the presence of morphological changes when all identifiable histopathology has been excluded, ${ }^{17}$ and the absence of 
gliosis in those areas of the temporal lobe in which the morphological changes are most pronounced. ${ }^{33-35}$

In the present study brain weight and length were related to poor premorbid academic and global function, relations that might be explained in terms of an early failure of development. Brain length is clearly likely to depend to some extent on skull size and shape, and there are inconsistent reports of differences in cranial size and shape between schizophrenic patients and controls. ${ }^{36}$

By contrast the presence of focal damage was unrelated to aspects of the clinical state (although more often seen in females) and is more difficult to explain in terms of existing publications. In a series of 100 brains of patients with major psychosis, Jellinger ${ }^{37}$ identified Alzheimer-type changes in 11, and evidence of vascular encephalopathy in a further eight, but in a series of 117 control brains collected at about the same time, Alzheimer-type changes were present in nine and vascular encephalopathy in 14. Therefore no general relation between schizophrenia and focal changes in the brain (such as might be associated with vascular encephalopathy) was found.

At first glance the findings of the present study offer support to the notion that there are at least two routes to the clinical picture of schizophrenia-one involving reduction in brain weight and length and associated with global and cognitive impairments and with negative features, and the other associated with focal damage and female sex. This interpretation may, however, be incorrect. Although focal damage was varied in nature, much of it was clearly vascular in origin (table 1 and appendix, Bruton et $a l^{17}$ ) and indeed the stated presence of focal damage was significantly associated with a histopathological judgement of the presence of cerebrovascular disease $(p<0.001)$. The control group consisted of patients who were examined postmortem because they died suddenly and unexpectedly. Those whose general practice records gave any history of neurological or psychiatric disorder were excluded. Although detailed information is not now available, it is likely that the exclusion criteria included transient vascular episodes. The schizophrenic patients were not screened for disorders of this kind, and it is possible that the increased evidence of focal cerebral damage (especially of a vascular nature) in these patients compared with the controls reflects the mode of selection rather than the schizophrenic process. Furthermore, it seems improbable that cerebrovascular disease present at death (at average age 68 in men and 79 in women) could be causally related to a psychotic disorder typically arising in early adult life. The difference in age of death between men and women may be relevant to the excess of focal damage in the female compared with the male schizophrenic, although no such differences were found in normal controls even though the two groups were closely matched for age and sex. Furthermore, interpretation of these findings must be tempered by the small numbers in the subsets and the large number of comparisons.

In conclusion, we regard it as possible, although not proved, that the excess of focal damage and gliosis in the patient group can be accounted for by factors unrelated to the schizophrenic disease process. This would be consistent with the findings of the present study that gross morphological change (for example, in brain weight and length) is correlated with features of the disease (for example, cognitive impairment and negative symptoms), whereas no clinical correlates of the presence of focal damage have been identified.

1 Griesinger W. Mental pathology and therapeutics. Translated by C Lockhart Robertson, J Rutherford. London: New Sydenham Society, 1857.

2 Clouston TS. The neuroses of development, being the Morison lectures of 1890. Edinburgh: Oliver and Boyd, 1891.

3 Kraepelin E. Psychiatrie. 5th ed. Leipzig: Barth, 1896.

Kraepelin E. Lerbuch der Psychiatrie. Translated by AR Diefendorf. New York: Macmillan, 1907.

5 Alzheimer A. Beitrage zur pathologischen anatomie der Hirnrinde und zur anatomischen grundlage der psychosen. Monatsschr Psychiatr Neurol 1897;2:82-120.

6 Dunlap CB. Dementia Praecox: some preliminary observations on brains from carefully selected cases and a vations on brains from carefully selected cases and a consideration of cert

7 David GB. The pathological anatomy of the schizophrenias. In: Richter D, ed. Schizophrenia, somatic aspects. New York: Pergamon Press, 1957:93-130.

8 Jacobi W, Winkler $H$. Encepahalographische studien an chronische schizophrenen. Arch Psychiatr Nervenkrankh 1927;81:299-322.

9 Hounsfield GN. Computerised transverse axial scanning (tomography) Part I: description of the system. $\mathrm{Br} \mathcal{F}$ Radiol 1973;46:1016-22.

10 Johnstone EC, Crow TJ, Frith CD, Husband J, Kreel L. Cerebral ventricular size and cognitive impairment in chronic schizophrenia. Lancet 1976;ii:924-6.

11 Zec RF, Weinberger DR. Relationship between CT scan findings and neuropsychological performance in chron schizophrenia. Psychiatr Clin North Am 1986;9:49-61. Psychiatry 1982;39:1131-9.

13 Kovelman JA, Schiebel AB. A neurohistological correlate of schizophrenia. Biol Psychiatry 1984;19:1601-21.

14 Jakob H, Beckmann H. Prenatal development disturbances in the limbic allocortex in schizophrenics. I Neural Transm 1986;65:303-26.

15 Brown R, Colter N, Corsellis JAN, et al. Postmortem evidence of structural brain changes in schizophrenia: differences in brain weight, temporal horn area and parahippocampal gyrus compared with affective disorder. Arch Gen Psychiatry 1986;43:36-42.

16 Pakkenberg B. Post mortem study of chronic schizophrenic brains. Br f Psychiatry 1987;151:744-52.

17 Bruton CJ, Crow TJ, Frith CD, Johnstone EC, Owens DGC, Roberts GW. Schizophrenia and the brain: a prospective cliniconeuropathological study. Psychol Med 1990;20:285-304.

18 Owens DGC, Johnstone EC. The disabilities of chronic schizophrenia, their nature and the factors contributing schizophrenia, their nature and the factors contributing
to their development. Br $\mathcal{F}$ Psychiatry 1980;136:384-95.

19 Owens DGC, Johnstone EC, Frith CD. Spontaneous involuntary disorders of movement: their prevalence, involuntary disorders of movement: their prevalence, severity and distribution in chronic schizophrenics with
and without treatment with neuroleptics. Arch Gen and without treatment with
Psychiatry 1982;39:452-61.

20 Ferrier IN, Johnstone EC, Crow TJ, Rincon-Rodriguez I. Anterior pituitary hormone secretion in chronic schizophrenia. Arch Gen Psychiatry 1983;40:755-61.

21 Owens DGC, Johnstone EC, Crow TJ, Frith CD, Jagoe JR, Kreel LL. Lateral ventricular size in schizophrenia. Relationships to the disease process and its clinical manifestations. Psychol Med 1985;15:27-41.

22 Johnstone EC, Owens DGC, Frith CD, Crow TJ. The relative stability of positive and negative features in chronic schizophrenia. Br ₹ Psychiatry 1987;150:60-4.

23 Feighner JP, Robins E, Guze SB, Woodruff A, Winokur G, Munoz R. Diagnostic criteria for use in psychiatric research. Arch Gen Psychiatry 1972;26:57-63.

24 Krawiecka M, Goldberg D, Vaughan M. Standardised psychiatric assessment scale for rating chronic psychotic psychiatric assessment scale for rating chronic p.
patients. Acta Psychiatr Scand 1977;55:299-308.

patients. Acta Psychiatr Scand 1977;55:299-308.
25 Withers E, Hinton J. Three forms of the clinical tests of the ithers E, Hinton J. Three forms of the clinical tests of the
sensorium and their reliability. Br $f$ Psychiatry 1971; 119:1-8.

26 Johnstone EC. Heterogeneity in schizophrenia. In: 
Lindenmeyer JP, Kay SR eds. New biological vistas on schizophrenia. Brunner Mazel: New York, 1992.

27 Frith CD, Leary J, Cahill C, Johnstone EC. Performance on psychological tests. Demographic and clinical correlates of the results of these tests. In: Johnstone EC, ed. Disabilities and circumstances of schizophrenic patients-a Disabilities and circumstances of schizophrenic patients-

28 Pearlson GD, Kim WS, Kubos KL, et al. Ventricle brain ratio, computer tomographic density and brain area in 50 schizophrenics. Arch Gem Psychiatry 1989;46:690-7.

29 Johnstone EC, Owens DGC, Bydder GM, Colter N, Crow TJ, Frith CD. The spectrum of structural brain changes in schizophrenia: age of onset as a predictor of cognitive and clinical impairments and their cerebral correlates. Psychol Med 1989;19:91-103.

30 Zipursky RB, Lim KO, Sullivan EV, Brown BW, Pfefferbaum A. Widespread cerebral grey matter volume deficits in schizophrenia. Arch Gen Psychiatry 1992;49: 195-205.

31 Harvey I, McGuffin JP, Williams $M$, Toone BU. The ventricle brain ratio (VBR) in functional psychoses: an admixture analysis. Psychiatry Res 1990;35:61-9.

32 Daniel DG, Goldberg TE, Gibbons RD, Weinberger DR Lack of bimodal distribution of ventricular size in schizophrenia: a Gaussian mixture analysis of 1056 cases and controls. Biol Psychiatry 1992;30:887-903.

33 Roberts GW, Colter N, Lofthouse R, Bogerts B, Zech M, Crow TJ. Gliosis in schizophrenia. Biol Psychiatry 1986;21:1043-50.

34 Roberts GW, Colter N, Lofthouse R, Johnstone EC, Crow TJ. Is there gliosis in schizophrenia? Biol Psychiatry

35 Crow TJ, Ball J, Bloom SR, et al. Schizophrenia as an anomaly of development of cerebral asymmetry. Arch Gen Psychiatry 1989;46:1 145-50.

36 Grove WM, Lebow BS, Medus C. Head size in relation to schizophrenia and schizotypy. Schizophr Bull 1991;17: 157-61.

37 Jellinger $\mathrm{K}$. Neuromorphological background of pathochemical studies in major psychoses. In: Beckman $\mathbf{H}$, Riederer P, eds. Pathochemical markers in major psychoses. Heidelberg: Springer Verlag, 1985:1-23. 